\title{
ANALISIS LAPORAN KEUANGAN UNTUK MENENTUKAN POSITIONING PERUSAHAAN PADA PT INKA MULTI SOLUSI TRADING TAHUN 2015-2016
}

\author{
Hengky Novia Putra ${ }^{1}$ \\ Pendidikan Akuntansi FKIP \\ Universitas PGRI Madiun \\ hengkynoviap@gmail.com
}

\author{
Satrijo Budiwibowo ${ }^{2}$ \\ Pendidikan Akuntansi FKIP \\ Universitas PGRI Madiun \\ Satrijobudiwibowo@yahoo.com
}

\author{
Juli Murwani ${ }^{3}$ \\ Pendidikan Akuntansi FKIP \\ Universitas PGRIMadiun \\ jmurwani@yahoo.com
}

\begin{abstract}
ABSTRAK
Penelitian ini bertujuan untuk menganalisis laporan keuangan untuk menentukan positioning perusahaan pada PT INKA Multi Solusi Trading Madiun tahun 2015-2016. Jenis penelitian yang digunakan adalah penelitian kualitatif. Metode pengolahan data dengan menggunakan analisis rasio keuangan likuiditas, rasio solvabilitas dan rasio rentabilitas. Positioning dilakukan untuk melihat baik atau buruknya kondisi keuangan pada perusahaan PT Inka Multi Solusi Trading Madiun. Pengumpulan data dalam penelitian menggunakan observasi, wawancara dan dokumentasi. Teknik analisis data yang digunakan meliputi metode deskriptif. Hasil penelitian menunjukkan bahwa kondisi dan kinerja keuangan perusahaan dalam posisi baik karena rasio likuditas diatas angka satu dan menunjukkan batas aman. Rasio solvabilitas perusahaan juga menunjukan hal yang baik dimana proporsi pendanaan dari lingkup eksternal menurun. Sedangkan rasio rentabilitas menunjukkan perusahaan bertumbuh ke arah positif ditandai dengan peningkatan penjualan bersih dan laba perusahaan yang cukup signifikan.
\end{abstract}

Kata Kunci : $\quad$ Analisis Keuangan; Rasio Keuangan; Positioning

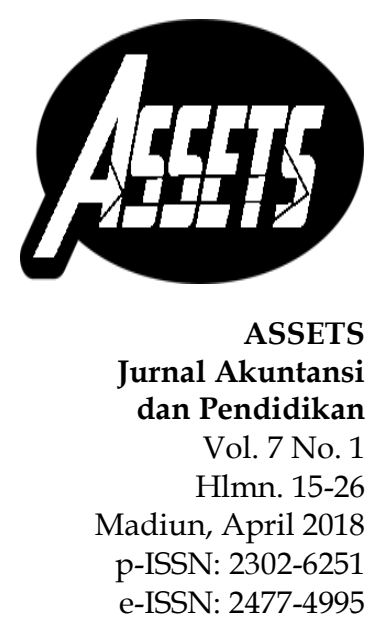

Artikel masuk: 24 Oktober 2017 Tanggal diterima: 5 Februari 2018 


\section{PENDAHULUAN}

Posisi Keuangan atau financial position yaitu gambaran pada suatu keadaan keuangan perusahaan yang ditunjukkan oleh nilai kekayaan (harta) dan hutang perusahaan yang tercermin dari neraca perusahaan tersebut. Laporan posisi keuangan atau sering disebut neraca, melaporkan aset, liabilitas dan modal entitas pada tanggal tertentu. Laporan keuangan merupakan sarana informasi dan komunikasi antara manajemen dengan pihak-pihak yang berkepntingan. Laporan keuangan mampu menunjukkan kinerja keuangan yang merefleksikan kinerja manajemen dalam suatu periode akuntansi.

Tujuan utama dari laporan keuangan adalah menyediakan informasi yang menyangkut posisi keuangan, kinerja dan perubahan posisi keuangan yang bermanfaat bagi sejumlah besar pemakai dalam pengambilan keputusan ekonomi serta menunjukan pertanggung jawaban manajemen atas penggunaan sumber-sumber daya yang dipercayakan kepada mereka (pemakai). Laporan keuangan tidak menyediakan semua informasi yang mungkin dibutuhkan pemakai dalam mengambil keputusan ekonomi karena secara umum menggambarkan pengaruh keuangan dan kejadian masa lalu, dan tidak untuk menyediakan informasi nonkeuangan.

Analisis laporan keuangan menurut Harahap (2011:190) adalah analisis laporan keuangan yaitu menguraikan pos-pos laporan keuangan menjadi unit informasi yang lebih kecil dan melihat hubungannya yang bersifat signifikan atau yang mempunyai makna antara satu dengan yang lainnya baik antara data kuantitatif maupun data non kuantitatif dengan tujuan untuk mengetahui kondisi keuangan lebih dalam yang sangat penting dalam proses menghasilkan keputusan yang sangat tepat. Menururt Harahap (2011:107) neraca atau daftar neraca disebut juga laporan posisi keuangan perusahaan, laporan ini menggambarkan posisi aset, kewajiban dan ekuitas pada saat tertentu. Neraca atau balance sheet adalah laporan keuangan yang menyajikan sumber-sumber ekonomis dari suatu perusahaan atau aset kewajiban-kewajibannya atau hutang, dan para pemilik perusahaan yang tertanam dalam perusahaan tersebut atau ekuitas pemilik suatu saat tertentu. Laporan laba rugi (income statement) mengukur kinerja selama beberapa periode waktu, biasanya setiap kuartal atau setiap tahun.

Likuiditas merupakan indikasi kecepatan suatu aset perusahaan untuk dikonversi menjadi kas. Rasio likuiditas merupakan suatu indikator mengenai kemampauan perusahaan membayar semua kewajiban finansial jangka pendek pada saat jatuh tempo dengan menggunakan aktiva lancar yang tersedia. Likuiditas tidak hanya berkenaan dengan keadaan keseluruhan keuangan perusahaan, tetapi juga berkaitan dengan kemampuannya mengubah aktiva lancar tertentu menjadi uang kas.

Menurut Riyanto (2013:32) solvabilitas suatu perusahaan menunjukkan kemampuan perusahaan untuk memenuhi segala kewajiban finansialnya apabila sekiranya perusahaan tersebut pada saat itu dilikuidasikan. Solvabilitas dimaksudkan sebagai kemampuan suatu perusahaan untuk membayar semua hutangnya (baik jangka pendek maupun jangka panjang).

Menurut Harahap (2009:304) Perusahaan melakukan kegiatan usaha selalu didasari keinginan untuk memperoleh laba atau keuntungan. Profitabilitas adalah hasil akhir dari sejumlah kebijakan dan keputusan yang dilakukan oleh perusahaan. Profitabilitas menggambarkan kemampuan perusahaan mendapatkan laba melalui semua kemampuan dan sumber daya yang ada seperti kegiatan penjualan, kas, modal, jumlah karyawan, jumlah cabang perusahaan, dan lain sebagainya.

PT. INKA Multi Solusi Trading Madiun merupakan anak perusahaan dari PT. INKA yang bergerak pada bidang industri perkeretaapian di Indonesia, dimana PT. 


\section{ASSEES JURNAL AKUNTANSI DAN PENDIDIKAN

INKA Multi Solusi Trading Madiun berdiri sejak Juli 2015, berdasarkan Akta Notaris Sri Wahyuni, SH Nomor 154 tanggal 28 Juli 2015. Kepemilikan saham PT. INKA Multi Solusi 95\% dan sisanya Perkumpulan Keluarga Besar INKA sebesar 5\%. Alamat kantor di Jalan dr. Sutomo Nomor 21 Madiun. PT. INKA Multi Solusi Trading bergerak untuk pekerjaan pengadaan dan logistik komponen baik di bidang perkeretaapian maupun transportasi lainnya.

Pada era globalisasi saat ini dalam bidang industri persaingan semakin kian berkembang dan penuh tantangan sehingga menuntut beberapa perusahaan untuk lebih inovatif dalam menghasilkan suatu produk untuk mempertahankan kelangsungan produk dan perusahaan. Hal ini berdampak kepada PT. INKA Multi Solusi Trading Madiun bahwa dalam dunia industri kita harus bisa berinovasi dengan apa yang diperlukan dan dibutuhkan oleh konsumen, sebagai industri di bidang pengadaan barang pada industri transportasi perkeretaapian yang merupakan satusatunya yang ada di Indonesia, sehingga harus bias memenuhi kebutuhan dari konsumen dan pasar international khususnya karena perkeretaapian Indonesia sudah bias menembus pasar internasional dan menjalin kerja sama dengan Jepang. Selain harus bias berinovasi dan berkembang dalam memenuhi kebutuhan konsumen dalam bidang trasportasi tentunya juga harus melihat dari sisi lain sehingga untuk menilai keberhasilan suatu perusahaan sangatlah perlu untuk mengetahui kondisi keuangan perusahaan yang dapat diketahui dari laporan keuangan yang ada pada PT. INKA Multi Solusi Trading Madiun, yang terdiri dari neraca, laporan perhitungan rugi laba serta laporan-laporan keuangan lainnya. Dengan mengadakan analisis terhadap pospos neraca akan dapat diketahui atau akan diperoleh gambaran tentang posisi keuangan perusahaan PT.INKA Multi Solusi Trading Madiun, sedangkan analisis terhadap laporan rugi labanya akan memberikan gambaran tentang hasil atau perkembangan usaha perusahaan PT.INKA Multi Solusi Trading Madiun.

Menurut wawancara yang telah dilakukan pada salah seorang pekerja bagian keuangan pada PT. INKA Multi Solusi Trading Madiun, bahwa laporan keuangan yang dijalankan pada PT. INKA Multi Solusi Trading Madiun berupa laporan keuangan pada umumnya yang terdiri dari neraca, laporan laba rugi, laporan perubahan modal, dan dari laporan keuangan perusahaan sudah adanya kerjasama dengan pihak Badan Pemeriksa Keuangan (BPK) untuk mengelola keuangan perusahaan.

Pongoh (2013) Menilai Kinerja Keuangan PT. Bumi Resources Tbk berdasarkan tingkat penjualan yang kemudian dianalisis menggunakan rasio rentabilitas, rasio likuiditas, rasio solvabilitas. Metode analisis data yang digunakan adalah metode deskriptif kuantitatif yang menggunakan pengukuran rasio rentabilitas, likuiditas, solvabilitas. Berdasarkan rasio likuiditas secara keseluruhan keadaan perusahaan berada dalam keadaan baik. Berdasarkan rasio solvabilitas keadaan perusahaan pada posisi solvable. Berdasarkan rasio rentabilitas keadaan perusahaan berada pada dalam posisi baik. Penelitian ini merupakan replikasi dari penelitian tersebut namun dilakukan pada objek yang berbeda. Motivasi penelitian ini karena PT.Inka Multi Solusi Trading Madiun merupakan anak cabang perusahaan pembuat kereta api satusatunya yang ada di Indonesia. Di samping itu masih jarang penelitian yang mengungkapkan analisis kondisi keuangan perusahaan tersebut.

Laporan keuangan merupakan dasar untuk melakukan analisis kondisi perusahaan, untuk itu kita harus mengetahui sifat, cakupan, dan keterbatasannya sebelum menentukan alat analisis. Analisis rasio keuangan merupakan salah satu alat analisis yang dapat digunakan untuk memperoleh gambaran tentang perkembangan finansial suatu perusahaan. Tahapan selanjutnya dilakukan interprestasi terhadap 
dana finansial dari perusahaan bersangkutan, dimana data finansial itu tercermin didalam laporan keuangan.

Laporan keuangan bagi perusahaan PT.Inka Multi Solusi Trading Madiun digunakan sebagai penilaian dan mengevaluasi dari pekerjaan bagian pembukuan, tetapi untuk selanjutnya laporan keuangan tidak hanya sebagai penilaian dan pengevaluasi saja tetapi juga sebagai dasar untuk dapat menentukan posisi keuangan perusahaan tersebut, dimana dengan hasil analisa tersebut pihak-pihak yang berkepentingan mengambil suatu keputusan. Jadi untuk mengetahui posisi keuangan perusahaan serta hasil-hasil yang telah dicapai oleh perusahaan tersebut perlu adanya laporan keuangan dari perusahaan.

KERANGKA BERFIKIR

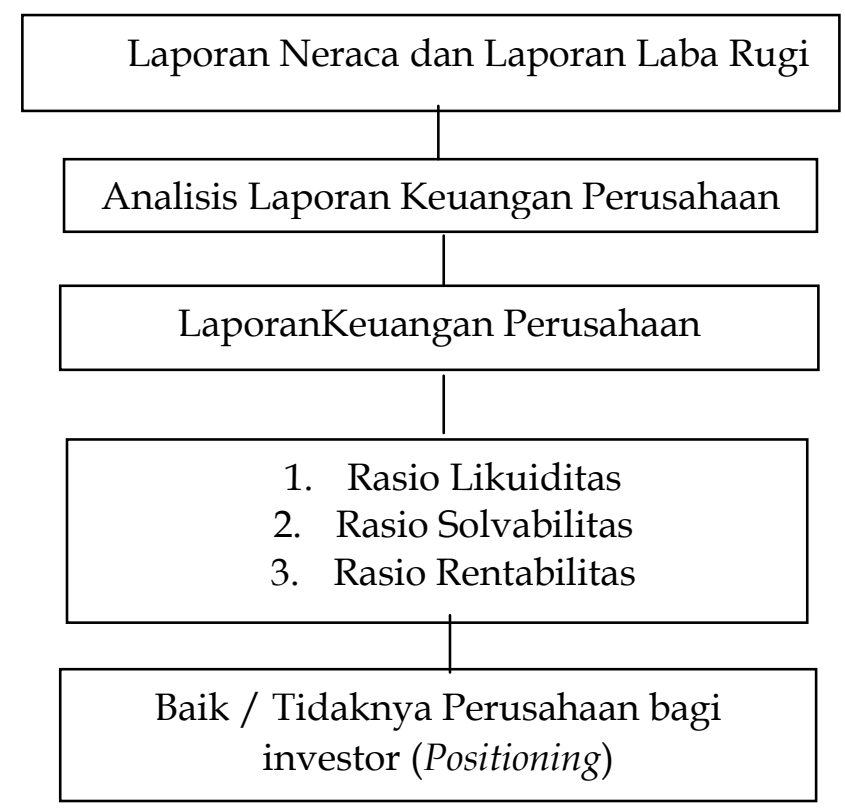

Gambar 1.KerangkaBerfikir

\section{METODE PENELITIAN}

Menurut Sugiyono (2015:37) metode penelitian kualitatif dinamakan metode postpositivistik karena berlandaskan pada filsafat postpositivisme. Metode ini disebut juga sebagai metode interpretive karena data hasil penelitian lebih berkenaan dengan interpretasi terhadap data yang ditemukan di lapangan. Penelitian kualitatif biasanya digunakan untuk meneliti pada kondisi obyek yang alamiah, (sebagai lawannya adalah eksperimen) dimana peneliti adalah sebagai instrumen kunci, pengambilan sampel sumber data dilakukan secara purposive dan snowball, teknik pengumpulan dengan triangulasi (gabungan), analisis data bersifat induktif/kualitatif, dan hasil penelitian kualitatif lebih menekankan makna dari pada generalisasi.

Sumber data dalam penelitian ini menggunakan data primer dan data sekunder. Data primer merupakan data yang diperolah dari sumber utamanya atau sumber asli. Menurut Sugiyono (2014:308) Sumber Primer adalah sumber data yang langsung memberikan data kepada pengumpul data. Data ini didapatkan dari hasil wawancara dengan kepala, karyawan atau staf yang terdapat pada PT.INKA Multi Solusi Trading Madiun. Pemilihan narasumber pada bagian keuangan perusahaan 
karena secara langsung berkaitan dalam hal penyusunan laporan keuangan perusahaan PT.INKA Multi Solusi Trading Madiun.

Data sekunder yang digunakan dalam penelitian ini adalah data laporan keuangan PT. INKA Multi Solusi Trading Madiun. Data laporan keuangan digunakan sebagai dasar melakukan analisis rasio. Hasil analisis rasio kemudian digabungkan dengan data primer untuk diinterprestasikan tentang kondisi perusahaan. Baik ataupun buruknya hasil interprestasi digunakan untuk menentukan posisi perusahaan.

Teknik pengumpulan data pada penelitian ini menggunakan:

1. Observasi

Observasi merupakan metode pengumpulan data dengan mengamati secara langsung. Observasi dalam penelitian ini dilakukan pada awal penelitian dengan observasi tak berstuktur. Setelah observasi awal, dapat diketahui kondisi perusahaan sehingga peneliti dapat menentukan fokus penelitian.

Ketika fokus penelitian telah diperoleh secara jelas, observasi selanjutnya menggunakan observasi terstruktur. Observasi terstruktur berupa observasi yang telah dirancang secara sistematis, tentang apa yang akan diamati, kapan dan dimana tempat penelitiannya dalam kaitannya pengumpulan data lebih lanjut.

2. Wawancara

Wawancara merupakan metode pengumpulan data dengan cara bertanya secara langsung sehingga interaksi komunikasi antara pihak peneliti dengan narasumber. Teknik wawancara yang biasanya dilakukan dalam penelitian kualitatif adalah wawancara mendalam.

Wawancara digunakan dalam pengumpulan data apabila peneliti ingin melakukan studi pendahuluan atau observasi untuk menemukan fokus penelitian yang harus diteliti, tetapi juga apabila peneliti ingin mengetahui hal-hal dari narasumber yang lebih mendalam dalam pengumpulan data. Dalam penelitian ini wawancara dilakukan dengan kepala, karyawan atau staf di bagian keuangan PT.INKA Multi Solusi Trading Madiun. Pemilihan narasumber didasarkan pada keahlian atau kompetensi menurut bidangnya, yaitu kepala, karyawan atau staf Bidang Keuangan.

3. Dokumentasi

Dokumentasi merupakan metode yang digunakan untuk memperoleh data dengan melakukan penyelidikan terhadap benda-benda tertulis seperti buku-buku, literature, majalah, dokumen, peraturan-peraturan, dan lain sebagainya. Dokumentasi yang dilakukan oleh peneliti dalam penelitian ini dokumen yang terkait dengan laporan neraca dan laporan laba rugi dalam penyusunan laporan keuangan pada PT.INKA Multi Solusi Trading Madiun.

Sebelum dilakukan analisis data, peneliti melakukan uji validitas dan reliabilitas sumber data dahulu. Uji validitas dan reliabilitas yang dilakukan dengan trianggulasi teknik yaitu observasi, wawancara dan dokumentasi. Data yang diperoleh dari ketiga teknik pengumpulan data tersebut diperbandingkan untuk menguji konsistensinya. Di samping itu, pada tahap wawancara juga dilakukan trianggulasi sumber yaitu informan yang diwawancara adalah sumber yang berbeda yaitu kepala bagian keuangan, staf bagian keuangan dan beberapa karyawan yang ada di PT. INKA Multi Solusi Trading Madiun.

Berdasarkan trianggulasi teknik dan trianggulasi sumber yang telah dilakukan, diperoleh hasil yang konsisiten antara data yang dperoleh dari informan, observasi dan dokumentasi. Untuk itu tahapan selanjutnya dlakukan analisis data. 
Dalam penelitian ini, untuk memecahkan masalah, maka penulis menggunakan metode deskriptif untuk mengiterprestasikan hasil analisis rasio keuangan likuiditas, rasio solvabilitas dan rasio rentabilitas yang telah dilakukan. Adapun metode perhitungan raso yang digunakan adalah sebagai berikut:

$$
\begin{aligned}
& \text { Current Ratio }=\frac{\text { Aktiva Lancar }}{\text { Hutang Lanear }} \times 100 \% \\
& \text { Quick Ratio }=\frac{\text { Aktiva Lanoar-Persediaan }}{\text { Hutang Lancar }} \times 100 \% \\
& \text { Cash Ratio }=\frac{\text { KastSetana Kas }}{\text { Hutang Lancar }} \times 100 \% \\
& \text { Debt to equity ratio }=\frac{\text { Total Hutang }}{\text { Modal (equity) }} \\
& \text { Debt Ratio }=\frac{\text { Total Hutang }}{\text { Total Aktiva }} \\
& \text { Time Interest Earned }=\frac{\text { LabaBersih SebelumBungadanPajak }}{\text { BebanBunga }} \\
& \mathbf{G P M}=(\text { Laba Kotor } / \text { Penjualan Bersih }) \times 100 \% \\
& \mathbf{N P M}=(\text { Laba setelah pajak } / \text { Total Aktiva }) \times 100 \%
\end{aligned}
$$

Hasil dari analisis rasio tersebut diinterprestasikan untuk mengungkapkan kondisi keuangan perusahaan dalam keadaan baik atau buruk. Penilaian posisi dan kondisi perusahaan ini akan didasarkan pada beberapa literatur terkait dan segmen industry perusahaan, misalnya untuk quick ratio dikatakan dalam kondisi baik jika angka yang dihasilkan berkisar 1,5 atau diatas 1 .

\section{HASIL PENELITIAN DAN PEMBAHASAN}

Penelitian ini dilaksanakan di PT Inka Multi Solusi Trading Madiun atau disingkat PT IMS Trading Madiun yang didirikan oleh induk perusahaan yaitu PT Industri Kereta Api (Persero) Madiun. Di dalam penelitian ini peneliti menganalisis laporan keuangan yang ada pada PT. IMS Trading pada tahun 2015 sampai dengan 2016 dimana dalam menganalisis laporan keuangan tersebut menggunakan perhitungan rasio keuangan yaitu rasio likuiditas, rasio solvabilitas, dan rasio rentabilitas atau profitabilitas. Penggunaan perhitungan rasio tersebut peneliti mengukurnya melalui laporan neraca dan laporan laba rugi perusahaan, dimana dari hasil analisis tersebut bisa mengetahui baik atau buruknya perusahaan. Pada penelitian ini kegiatan analisis data meliputi pengolahan dan penyajian data, melakukan perhitungan untuk mendeskripsikan data dan melakukannya menggunakan metode deskriptif dengan menggunakan analisis rasio keuangan likuiditas, rasio solvabilitas dan rasio rentabilitas.

Tujuan yang ingin dicapai dari penelitian ini yaitu dengan menganalisis menggunakan rasio likuiditas untuk mengukur apakah perusahaan dapat dengan cepat membayarkan kewajiban jangka pendek dengan menggunakan aktiva yang dimiliki. Rasio solvabilitas digunakan untuk mengukur apakah perusahaan bisa membayarkan hutang atau kewajiban pada jangka pendek maupun jangka panjang, 


\section{ASSEIS JURNAL AKUNTANSI DAN PENDIDIKAN

sedangkan rasio rentabilitas digunakan untuk mengukur keuntungan atau laba yang diperoleh perusahaan selama satu periode. Penghitungan rasio keuangan difokuskan pada laporan neraca dan laporan laba rugi perusahaan PT IMS Trading, sehingga dapat dilakukan suatu perhitungan untuk laporan keuangan pada PT IMS Trading untuk tahun 2015-2016, yaitu sebagai berikut:

$\begin{array}{ll}\text { Current Ratio } & =(\text { Aktiva Lancar }) /(\text { Hutang Lancar) } \times 100 \% \\ \text { Current Ratio tahun } 2015 & =18.534 .600 .109 / 16.823 .955 .208 \times 100 \% \\ & =1,10 \\ \text { Current Ratio tahun } 2016 & =41.963 .805 .181 / 38.890 .946 .588 \times 100 \% \\ & =1,08\end{array}$

Current ratio PT Inka Multi Solusi Trading Madiun pada tahun 2015 sebesar 1,10 atau 110\%, sedangkan pada tahun 2016 menurun 0,02\% sebesar 1,08 atau 108\%. Penurunan ini disebabkan oleh meningkatnya hutang lancar, hutang lancar meningkat dari tahun 2015 ke tahun 2016 dikarenakan pada tahun 2015 hutang lain-lain yang dimiliki PT IMS Trading masih belum ada sehingga hutang yang dimiliki masih sedikit dibanding dengan tahun 2016 yang memiliki hutang lain-lain sebesar 17.480.124.244, sehingga untuk perhitungan menggunakan current ratio mengalami penurunan dari tahun 2015 ke tahun 2016.

$$
\begin{array}{lll}
\text { Quick Ratio } & =(\text { Aktiva Lancar-Persediaan }) /(\text { Hutang Lancar }) \times 100 \% \\
\text { Quick Ratio tahun } 2015 & =(18.534 .600 .109-510.336 .458) / 16.823 .955 .208 \times 100 \% \\
& =1,07 \\
\text { Quick Ratio tahun 2016 } & =(41.963 .805 .181-9.276 .066 .808) / 38.890 .946 .588 \times 100 \% \\
& =0,84
\end{array}
$$

Quick ratio PT Inka Multi Solusi Trading Madiun pada tahun 2015 sebesar 1,07 atau 107\%, sedangkan pada tahun 2016 mengalami penurunan 0,23\% sebesar 0,84 atau $84 \%$. Penurunan ini disebabkan oleh menurunnya jumlah aktiva lancar yang sedikit setelah dikurangi dengan persediaan, dalam perhitungan menggunakan quick ratio mengalami penurunan karena persediaan yang dimiliki PT IMS Trading dari tahun 2015 ke tahun 2016 mengalami peningkatan dalam persediaan dalam pengiriman yang dimiliki di tahun 2016 sebesar 9.276.066.808, sedangkan di tahun 2015 tidak memiliki persediaan dalam pengiriman dikarenakan masih tahun awal, tetapi memiliki sparepart sebesar 510.336.458, sehingga dalam perhitungan menggunakan quick ratio mengalami penurunan yang disebabkan oleh persediaan yang dimiliki mengalami peningkatan.
Cash Ratio
$=($ Kas $/$ Setara Kas $) /($ Hutang Lancar $) \times 100 \%$
Cash Ratio tahun 2015
$=517.165 .130 / 16.823 .955 .208 \times 100 \%$
$=0,03$
Cash Ratio tahun 2016$$
=7.101 .321 .844 / 38.890 .946 .588 \times 100 \%
$$$$
=0,18
$$

Cash ratio PT Inka Multi Solusi Trading Madiun pada tahun 2015 sebesar 0,03 atau 3\%, sedangkan pada tahun 2016 mengalami kenaikan 0,15 sebesar 0,18 atau 18\%. Kenaikan ini disebabkan oleh meningkatnya kas/setara kas, hal ini dikarenakan pada tahun 2015 kas yang dimiliki sebesar 35.937.663 sedangkan setara kas yang dimiliki hanya dari Bank Mandiri sebesar 481.227.467, dan pada tahun 2016 kas yang dimiliki sebesar 36.314 .000 sedangkan setara kas yang dimiliki dari beberapa bank yang cukup banyak yaitu dari Bank Mandiri sebesar 3.791.781.041, Bank Rakyat Indonesia sebesar 1.038.685.931, bank bukopin sebesar 1.009.967.956, Bank Syariah Mandiri sebesar 1.002.004.641, dan bank panin sebesar 4.749.889, sehingga pada tahun 2016 mengalami 
peningkatan kas dan setara kas yang cukup banyak dibandingkan tahun 2015, sehingga dalam perhitungan menggunakan cash ratio mengalami peningkatan yang disebabkan oleh kas dan setara kas.

Debt to equity ratio

Debt to equity ratio tahun 2015

$=($ Total Hutang $) /($ Modal (equity) $)$

$=16.823 .955 .208 / 1.719 .841 .502$

$=9,78$

Debt to equity ratio tahun 2016

$=38.890 .946 .588 / 6.429 .255 .275$

$=6,05$

Debt to equity ratio PT Inka Multi Solusi Trading Madiun pada tahun 2015 sebesar 9,78 atau 978\%, sedangkan pada tahun 2016 mengalami penurunan 3,73 sebesar 6,05 atau 605\%. Penurunan ini disebabkan oleh meningkatnya jumlah modal, dalam hal ini modal yang dimiliki tahun 2016 mengalami peningkatan dibanding tahun 2015 karena pada tahun 2016 saldo awal dan laba komprehensif tahun berjalan yang dimiliki cukup besar yaitu sebesar 5.765.465.651, sedangkan pada tahun 2015 untuk saldo awal masih belum ada dikarenakan masih tahun awal dan untuk laba komprehensif tahun berjalan yang dimiliki yaitu sebesar 844.841.502. sehingga untuk perhitungan menggunakan debt to equity ratio mengalami penurunan yang disebabkan modal yang miliki PT IMS Trading yang meningkat.
Debt Ratio
$=($ Total Hutang $) /($ Total Aktiva $)$
Debt Ratio tahun 2015
$=16.823 .955 .208 / 18.543 .796 .710$
$=0,91$
Debt Ratio tahun 2016

$$
\begin{aligned}
& =38.890 .946 .588 / 45.320 .201 .863 \\
& =0,86
\end{aligned}
$$

Debt ratio PT Inka Multi Solusi Trading Madiun pada tahun 2015 sebesar 0,91 atau 91\%, sedangkan pada tahun 2016 mengalami penurunan 0,05 sebesar 0,86 atau $86 \%$. Penurunan ini disebabkan oleh meningkatnya jumlah aktiva dengan jumlah hutang, dalam hal ini aktiva yang dimiliki dari tahun 2015 ke tahun 2016 mengalami peningkatan dikarenakan aset tetap yang dimiliki pada tahun 2016 mengalami peningkatan sebesar 3.137.042.798 dibandingkan pada tahun 2015 yang hanya sebesar 9.196.601, sedangakan untuk hutang yang dimiliki mengalami peningkatan dari tahun 2015 ke tahun 2016 dikarenakan pada tahun 2015 hutang lain-lain yang dimiliki PT IMS Trading masih belum ada dibanding dengan tahun 2016 yang memiliki hutang lain-lain sebesar 17.480.124.244, sehingga dalam perhitungan dengan menggunakan debt ratio mengalami penurunan.

Time Interest Earned $\quad=($ Laba Bersih Sebelum Bunga dan Pajak $) /($ Beban Bunga $)$

Time Interest Earned tahun $2015 \quad=1.082 .235 .502 / 0$

Time Interest Earned tahun2016 = $\quad=6.557 .263 .515 / 1.344 .050 .656$

$$
=4,88
$$

Time interest earned Pt Inka Multi Solusi Trading Madiun pada tahun 2015 sebesar 0\%, sedangkan pada tahun 2016 mengalami peningkatan 4,88 sebesar 4,88 atau $488 \%$. Peningkatan ini disebabkan oleh meningkatnya beban bunga, beban bunga meningkat dari tahun awal 2015 ke tahun 2016 dikarenakan pada tahun awal masih belum adanya pinjaman kepada pihak bank sehingga masih belum adanya beban bunga pada tahun 2015 sedangkan pada tahun 2016 beban bunga yang dimiliki dari pinjaman kepada bank sebesar 1.344.050.656. Perhitungan dengan menggunakan time 


\section{ASSEES JURNAL AKUNTANSI DAN PENDIDIKAN

interest earned mengalami peningkatan yang cukup besar dari tahun 2015 ke tahun 2016.

$\begin{array}{ll}\text { Gross Profit Marginal } & =(\text { Laba Kotor / Penjualan Bersih }) \times 100 \% \\ \text { Gross Profit Marginal tahun 2015 } & =(1.505 .372 .445 / 18.538 .302 .942) \times 100 \% \\ & =0,08 \\ \text { Gross Profit Marginal tahun 2016 } & =(12.696 .578 .421 / 75.483 .106 .757) \times 100 \% \\ & =0,17\end{array}$

Gross profit marginal PT Inka Multi Solusi Trading Madiun pada tahun 2015 sebesar 0,08 atau 8\%, sedangkan pada tahun 2016 mengalami peningkatan 0,09 sebesar 0,17 atau $17 \%$. Peningkatan ini disebabkan oleh meningkatnya penjualan bersih, dalam hal ini penjualan bersih yang diterima mengalami peningkatan yang cukup besar dari tahun 2015 ke tahun 2016, yaitu untuk penjualan bersih di tahun 2015 yang diterima sebesar 18.538.302.942 sedangkan untuk tahun 2016 penjualan bersih yang diterima sebesar 75.483.106.757. Perhitungan dengan menggunakan gross profit marginal mengalami peningkatan dan dalam kaitan ini perhitungan bisa dikatakan baik karena laba yang dicapai mengalami peningkatan.

$\begin{array}{ll}\text { Net Profit Marginal } & =(\text { Laba setelah pajak / Total Aktiva }) \times 100 \% \\ \text { Net Profit Marginal tahun 2015 } & =(844.841 .502 / 18.543 .796 .710) \times 100 \% \\ & =0,05 \\ \text { Net Profit Marginal tahun } 2016 & =(4.920 .624 .149 / 45.320 .201 .863) \times 100 \% \\ & =0,11\end{array}$

Net profit marginal PT Inka Multi Solusi Trading Madiun pada tahun 2015 sebesar 0,05 atau 5\%, sedangkan pada tahun 2016 mengalami peningkatan 0,06 sebesar 0,11 atau $11 \%$. Peningkatan ini disebabkan oleh meningkatnya laba setelah pajak, hal ini dikarenakan pada tahun 2015 laba setelah pajak yang dimiliki sebesar 844.841.502, sedangkan untuk tahun 2016 laba setelah pajak yang dimiliki sebesar 4.920.624.149, sehingga untuk perhitungan menggunakan net profit margin mengalami peningkatan dan dalam kaitan ini bisa dikatakan baik dalam mendapatkan laba dari PT IMS Trading.

Dari hasil pembahasan diatas dengan menggunakan perhitungan analisis rasio keuangan, maka dapat disimpulkan bahwa:

1. Berdasarkan analisis yang telah dilakukan, likuiditas PT. INKA Multi Solusi Trading Madiun dalam kondisi yang cukup baik karena angka yang dihasilkan dari perhitungan current ratio lebih besar dari 1 . Hal ini menunjukkan bahwa aset lancarnya masih lebih dari cukup untuk memenuhi hutang lancarnya. Jika dilihat dari hasil perhitungan quick ratio yang mengalami penurunan dan cash ratio mengalami peningkatan, hal ini masih dalam kondisi aman untuk perusahaan karena berdasarkan analsisis lanjutan, penurunan quick ratio disebabkan oleh komposisi persediaan yang lebih banyak di tahun 2016. Berdasarkan hasil wawancara dan analisis dokumen ditemukan bahwa peningkatan persediaan ini terjadi karena peningkatan jumlah permintaan pelanggan. Hal ini dapat dibuktikan dari jumlah penjualan perusahaan yang meningkat signifikan di tahun 2016. Peningkatan cash ratio yang cukup signifikasn mengindikasikan meningkatknya jumlah penjualan diikuti dengan cepatnya konversi menjadi kas. Berdasarkan beberapa analisis likuiditas tersebut dapat disimpulkan bahwa perusahaan dalam kondisi yang cukup baik.

2. Berdasarkan analisis solvabilitas yang telah dilakukan, ditemukan bahwa kondisi perusahaan mengalami peningkatan yang lebih baik. Penurunan nilai debt to equity 
ratio pada tahun 2016 menunjukkan proporsi pendanaan dari lingkup eksternal menurun dan pendanaan lingkup internal naik. Hal ini disebabkan oleh adanya pertumbuhan laba perusahaan yang cukup signifikan. Hasil perhitungan debt ratio juga mengalami penurunan yang mengindikasikansikan bahwa peningkatan jumlah aktiva yang dimiliki perusahaan bukan bersumber dari hutang, melainkan dari sumber internal yaitu peningkatan laba. Hal ini menunjukkan kondisi yang cukup baik.

3. Rasio rentabilitas yang menggunakan gross profit marginal dan net profit marginal mengalami peningkatan yang disebabkan oleh meningkatnya penjualan bersih, sehingga mengakibatkan laba yang diperoleh perusahaan juga meningkat. Hasil ini mendukung analisis likuiditas dan solvabilitas yang menunjukkan perusahaan dalam kondisi baik dan pertumbuhan positif ini bersumber dari peningkatan penjualan dan laba perusahaan.

\section{SIMPULAN}

Perhitungan untuk mengetahui laporan keuangan melalui rasio likuiditas, rasio solvabilitas, dan rasio rentabilitas/profitabilitas tahun 2015-2016 pada PT INKA Multi Solusi Trading Madiun. Rasio likuiditas dalam penelitian ini menggunakan current ratio, quick ratio, cash ratio. Rasio solvabilitas yang digunakan adalah debt to equity ratio, debt ratio dan time interest earned. Rasio rentabilitas menggunakan gross profit marginal dan net profit marginal.

Positioning perusahaan dari laporan rugi laba dan laporan neraca tahun 20152016 pada PT INKA Multi Solusi Trading Madiun berada pada kondisi likuid dan solvable, dimana likuid dikarenakan aktiva lancar, kas yang dimiliki dapat menjamin hutang lancarnya, sedangkan solvable dikarenakan debt ratio dan debt to equity ratio yang dengan nilai menurun menunjukkan bahwa pertumbuhan perusahaan mengarah ke positif sehingga mampu menjamin pemenuhan hutang jangka pendek dan jangka panjangnya di masa mendatang. Hasil perhitungan rasio rentabilitas menunjukkan bahwa pertumbuhan penjualan bersih dan laba perusahaan meningkat dari $2015 \mathrm{ke}$ tahun 2016. Hal ini juga memberikan indikasi bahwa posisi perusahaan dalam kondisi baik.

Keterbatasan penelitian ini hanya menggunakan beberapa rasio dalam penilaian likuiditas, solvabilitas dan rentabilitas. Untuk penelitian di masa mendatang diharapkan menggunakan menambahkan rasio-rasio lain yang lebih kompleks ataupun ditambahkan penilaian pertumbuhan perusahaan secara historis ataupun fundamental. Di samping itu rentang penelitian hanya menggunakan data dua tahun. Untuk penelitian selanjutnya dapat menggunakan rentang lima sampai dengan sepuluh tahun agar dapat menangkap tren perkembangan perusahaan sehingga mampu melakukan forecasting dan penyusunan laporan proforma perusahaan untuk melakukan penilaian posisi perusahaan secara komprehensif.

\section{DAFTAR PUSTAKA}

Budiwibowo, S. (2013). Analisis Rasio Keuangan Sebagai Alat Ukur Kinerja Perusahaan Pada PT. Astalia Millenia Educatindo Cabang Madiun. Assets: Jurnal Akuntansi dan Pendidikan. 2(1), 25-40.

Harahap, S.S. (2011). Teori Akuntansi. Jakarta : PT Raja Grafindo Persada.

Maith, H.A. (2013). Analisis Laporan Keuangan dalam Mengukur Kinerja Keuangan pada PT Hanjaya Mandala Sampoerna Tbk. Jurnal EMBA. 1(3), 619-628.

Pongoh, M. (2013). Analisis Laporan Keuangan untuk Menilai Kinerja Keuangan PT Bumi Resources Tbk. Jurnal EMBA. 1(3), 669-679. 


\section{ASSEIS JURNAL AKUNTANSI DAN PENDIDIKAN

Riyanto, B. (2013). Dasar-Dasar Pembelanjaan Perusahaan. Yogyakarta : BPFEYogyakarta.

Sugiyono. (2015). Metode Penelitian Kuantitatif, Kualitatif, dan Kombinasi (Mixed Methods). Bandung: Alfabeta.

Sugiyono. (2014). Metode Penelitian Pendidikan (Pendekatan Kuantitatif, Kualitatif, dan R\&D). Bandung: Alfabeta.

\section{LAMPIRAN}

\begin{tabular}{|c|c|c|}
\hline No. & Indikator & Pertanyaan \\
\hline 1. & Laporan keuangan & $\begin{array}{l}\text { 1. Apa yang perlu diperhatikan dalam penyusunan } \\
\text { laporan keuangan? } \\
\text { 2. Bagaimana tahap-tahap dalam penyusunan laporan } \\
\text { keuangan? } \\
\text { 3. Apa saja kendala yang dihadapi dalam penyusunan } \\
\text { laporan keuangan? } \\
\text { 4. Menurut anda apakah perhitungan laporan keuangan } \\
\text { sudah sesuai dengan peraturan PSAK IFRS? }\end{array}$ \\
\hline 2. & Rasio likuiditas & $\begin{array}{l}\text { 1. Menurut Anda, apakah di dalam penyusunan laporan } \\
\text { keuangan perlu dilakukan perhitungan melalui rasio } \\
\text { likuiditas? } \\
\text { 2. Apakah yang anda ketahui mengenai rasio likuiditas? } \\
\text { 3. Menurut anda apakah perhitungan menggunakan rasio } \\
\text { likuiditas sudah dilakukan dengan sesuai pada PT } \\
\text { IMST? } \\
\text { 4. Menurut anda untuk perhitungan yang saya lakukan } \\
\text { dengan menggunakan rasio likuiditas dari perhitungan } \\
\text { current ratio dan quick ratio yang mengalami penurunan } \\
\text { dari tahun } 2015 \text { ke tahun } 2016 \text { sudah sesuai? }\end{array}$ \\
\hline 3. & Rasio solvabilitas & $\begin{array}{l}\text { 1. Apakah yang menjadi dasar dalam penyusunan laporan } \\
\text { keuangan pada PT.INKA Multi Solusi Trading Madiun? } \\
\text { 2. Menurut Anda, apakah pengukuran dengan } \\
\text { menggunakan rasio solvabilitas perlu dalam pelaporan } \\
\text { keuangan PT.INKA Multi Solusi Trading Madiun? } \\
\text { 3. Menurut anda apakah perhitungan menggunakan rasio } \\
\text { solvabilitas sudah dilakukan dengan sesuai pada PT } \\
\text { IMST? } \\
\text { 4. Menurut anda untuk perhitungan yang saya lakukan } \\
\text { dengan menggunakan rasio solvabilitas dari } \\
\text { perhitungan debt to equity ratio dan debt ratio yang } \\
\text { mengalami penurunan dari tahun } 2015 \text { ke tahun } 2016 \\
\text { sudah sesuai? }\end{array}$ \\
\hline 4. & Rasio rentabilitas & $\begin{array}{l}\text { 1. Apakah yang anda ketahui tentang rasio rentabilitas? } \\
\text { 2. Menurut Anda, apakah pengukuran dengan } \\
\text { menggunakan rasio rentabilitas perlu dalam pelaporan } \\
\text { keuangan PT.INKA Multi Solusi Trading Madiun? } \\
\text { 3. Menurut anda apakah perhitungan menggunakan rasio } \\
\text { rentabilitas sudah dilakukan dengan sesuai pada PT } \\
\text { IMST? } \\
\text { 4. Menurut anda untuk perhitungan yang saya lakukan }\end{array}$ \\
\hline
\end{tabular}


PUTRA, H. N., BUDIWIBOWO, S. \& MURWANI, J. ANALISIS LAPORAN KEUANGAN ...

ASSETS

\begin{tabular}{|c|c|c|}
\hline No. & Indikator & Pertanyaan \\
\hline & & $\begin{array}{l}\text { dengan menggunakan rasio rentabilitas dari } \\
\text { perhitungan gross profit marginal dan net profit marginal } \\
\text { yang mengalami peningkatan dari tahun } 2015 \text { ke tahun } \\
2016 \text { sudah sesuai? }\end{array}$ \\
\hline 5. & Neraca & $\begin{array}{l}\text { 1. Apakah neraca perlu diungkapkan dalam pelaporan } \\
\text { keuangan? } \\
\text { 2. Menurut Anda, apakah tujuan neraca dalam pelaporan } \\
\text { keuangan? }\end{array}$ \\
\hline 6. & Laba rugi & $\begin{array}{l}\text { 1. Menurut Anda, apakah tujuan laba rugi dalam } \\
\text { pelaporan keuangan? } \\
\text { 2. Apakah dasar yang digunakan laba rugi dalam } \\
\text { pelaporan keuangan? }\end{array}$ \\
\hline
\end{tabular}

